\title{
KARAKTERISASI KERAGAMAN GENETIK POPULASI JABON PUTIH MENGGUNAKAN PENANDA RANDOM AMPLIFIED POLYMORPHISM DNA
}

Genetic diversity characterization of Anthocepalus cadamba population revealed by Random Amplified Polymorphism DNA

ILG. Nurtjahjaningsih, Maryatul Qiptiyah, Tri Pamungkas, AYPBC. Widyatmoko, Anto Rimbawanto

Balai Besar Penelitian Bioteknologi dan Pemuliaan Tanaman Hutan J1. Palagan Tentara Pelajar Km 15, Purwobinangun, Pakem, Sleman, Yogyakarta 55582 e-mail: iluh_nc@yahoo.com

\begin{abstract}
Anthocepalus cadamba (white jabon) has high economical value for furniture. White jabon forests severely degraded due to intensive exploitation and land conversion. Genetic diversity is one of important consideration to design conservation and improvement strategies. Aim of this study was to access the genetic diversity values within and among population of white jabon. Leaf samples of white jabon were collected from conservation plots originated from West Lombok, Sumbawa, South Sumatera and West Sumatera. Red jabon was included as an outgroup population. Based on 37 polymorphic RAPD loci, the results showed comparable value of genetic diversity between white jabon and red jabon. Number of detected and rare alleles was highest founded in Sumbawa population among the other three populations of white jabon. As consequence, value of expected heterozygosity in the population was highest $\left(H_{E}=0.315\right)$. Private allele was only detected in South Sumatera population. Principal coordinate analysis (PCA) showed that integrating between genetic and geographical distance was inconsistent; similar gene resources or human impact might be responsible for this result. The populations that have high value of genetic diversity and private allele are recommended to be selected for the conservation strategies, i.e. Sumbawa and South Sumatera.
\end{abstract}

Key word: white jabon, red jabon, outgroup, RAPD, genetic diversity

\begin{abstract}
ABSTRAK
Antocepalus cadamba (jabon putih) mempunyai nilai ekonomi tinggi untuk pertukangan. Hutan jabon putih banyak terdegradasi karena eksploitasi intensif dan konversi lahan. Keragaman genetik adalah salah satu pertimbangan penting untuk merancang strategi konservasi dan pemuliaan. Tujuan penelitian adalah untuk mengetahui nilai keragaman genetik di dalam dan antar populasi jabon putih. Contoh/cuplikan daun jabon putih dikumpulkan dari plot konservasi yang berasal dari Lombok Barat, Sumbawa, Sumatera Selatan dan Sumatera Barat. Penelitian ini menggunakan satu populasi jabon merah sebagai populasi pembanding. Berdasarkan 37 lokus RAPD polimorfik, hasil penelitian menunjukkan nilai keragaman genetik yang hampir sama antara jabon putih dan jabon merah. Jumlah allele yang terdeteksi dan allele yang jarang muncul mempunyai nilai paling tinggi di populasi Sumbawa diantara 3 populasi jabon putih yang lain. Hal ini menyebabkan nilai keragaman genetik harapan di populasi tersebut menunjukkan nilai tertinggi $\left(H_{\mathrm{E}}=0,315\right)$. Alel privat hanya ditemukan di populasi Sumatera Selatan. Analisis prinsip koordinat (PCA) menunjukkan bahwa jarak
\end{abstract}


genetik dan jarak geografis tidak saling berhubungan. Hal ini disebabkan oleh persamaan sumber genetik atau peran manusia. Populasi yang mempunyai nilai keragaman genetik tinggi dan allele privat direkomendasikan digunakan dalam strategi konservasi yaitu populasi Sumbawa dan Sumatera Selatan.

\section{Kata kunci: Jabon putih, jabon merah, populasi pembanding, RAPD, keragaman genetik}

\section{PENDAHULUAN}

Anthocepalus cadamba Miq. atau jabon putih merupakan salah satu tanaman yang berasal dari Asia Tenggara dan mempunyai nilai ekonomi tinggi untuk pertukangan (Krisnawati et al., 2011). Di Indonesia, jabon putih sudah ditanam dalam skala besar sejak tahun 1930-an. Selain itu karena mudah diperbanyak secara vegetatif, sebarannya cukup luas yaitu di pulau Jawa, Kalimantan, Sumatera, Sulawesi, Sumbawa dan Papua (Krisnawati et al., 2011). Jabon putih umumnya dijumpai pada hutan sekunder di sepanjang bantaran sungai dan daerah antara daerah berawa, daerah yang tergenang air secara permanen maupun secara periodik (Krisnawati et al., 2011).

Hingga saat ini, populasi jabon putih sudah semakin rusak karena eksploitasi intensif dan konversi pemanfaatan lahan. Selain itu karena kompetisi yang kuat antar tegakan, pada umumnya jabon putih tumbuh berasosiasi dengan jenis lain dan berkelompok yang terdiri dari 3-6 individu pohon (Pamungkas, komunikasi pribadi). Salah satu ancaman yang paling serius pada populasi terpisah-pisah adalah menurunnya keragaman genetik. Untuk mengatasi hal tersebut, strategi konservasi jabon putih sudah dimulai dengan dibangunnya petak konservasi ex situ. Selain digunakan sebagai petak konservasi genetik, petak tersebut juga diharapkan dapat digunakan sebagai materi genetik untuk pembangunan populasi dasar dalam strategi pemuliaan.

Keragaman genetik yang tinggi diperlukan untuk mempertahankan kehidupan suatu jenis dari serangan hamapenyakit, fitness dan adaptasi terhadap kondisi lingkungan. Banyak faktor yang mempengaruhi besarnya nilai keragaman genetik, di antaranya sifat reproduksi dan habitat di alam (Hamrick et al., 1992). Jenis yang sebaran serbuk sari maupun bijinya dibantu oleh angin, cenderung mempunyai laju menyerbuk silang dan keragaman genetik tinggi. Oleh karena itu, pada umumnya jenis konifer mempunyai nilai keragaman genetik 
yang lebih tinggi dibandingkan dengan jenis daun lebar (Moriguchi et al., 2004).

Struktur populasi yang menyambung dengan jumlah individu bereproduksi cukup banyak merupakan kondisi yang ideal, sehingga suatu populasi mampu mempertahankan besarnya keragaman genetik (Butcher et al., 1998). Namun kondisi ideal tersebut jarang ditemukan di hutan alam (Manoel et al., 2012).

Informasi nilai keragaman genetik populasi jabon putih merupakan salah satu pertimbangan penting dalam menentukan strategi konservasi maupun pemuliaan yang dilakukan. Dengan pertimbangan bahwa jabon putih sudah disebarkan sejak kurun waktu cukup lama dalam wilayah di Indonesia yang luas, serta mudah diperbanyak secara vegetatif maka akan mempersulit identifikasi sumber benih, maupun identifikasi hutan alam atau tanaman pada kondisi hutan jabon putih yang ada sekarang. Selain itu, keterbatasan ketersediaan lahan konservasi mengharuskan suatu plot konservasi dirancang menggunakan populasi dengan nilai keragaman genetik yang memadai/ tinggi dengan perbedaan genetik antar populasi yang tinggi. Sistem pemisahan jalur antar populasi juga harus dilakukan untuk menghindari kontaminasi gen antar populasi sehingga menentukan kelayakan suatu plot konservasi yang digunakan sebagai populasi dasar dalam strategi pemuliaan. Identifikasi populasi jabon putih sudah dilakukan menggunakan morfologi biji (Pamungkas, komunikasi pribadi). Selanjutnya, identifikasi populasi jabon putih secara genetik akan menambah informasi sehingga dapat menyimpulkan identitas populasi dengan lebih akurat.

Tujuan penelitian ini adalah mengetahui nilai keragaman genetik di dalam dan antar populasi jabon putih. Peran penelitian ini adalah menginformasikan status keragaman genetik dan diharapkan dapat digunakan sebagai pertimbangan untuk meningkatkan efisiensi penyusunan strategi konservasi dan pemuliaan jabon putih.

\section{BAHAN DAN METODE}

\section{A. Lokasi penelitian}

Contoh daun jabon putih dikumpulkan dari petak konservasi yang dibangun oleh Balai Besar Penelitian Bioteknologi dan Pemuliaan Tanaman Hutan, terletak di Temanggal, Magelang (Jawa Tengah) dan Gunung Kidul (Daerah Istimewa Yogyakarta). 
Jabon putih berasal dari empat sebaran alamnya yaitu Lombok Barat, Sumbawa, Ogan Ilir (Sumatera Selatan) dan Pasaman (Sumatera Barat) (Gambar 1). Sebagai pembanding (out group), digunakan jabon merah yang berasal dari sebaran alam di Sulawesi Utara (Gambar 1). Pada penelitian ini, daerah sebaran alam tersebut selanjutnya diperlakukan sebagai populasi jabon putih yaitu Lombok Barat (lb), Sumbawa (sw), Ogan Ilir (Sumatera Selatan; ss), Pasaman (Sumatera Barat; sb) dan populasi jabon merah yaitu Sumatera Utara (su) (Tabel 1).

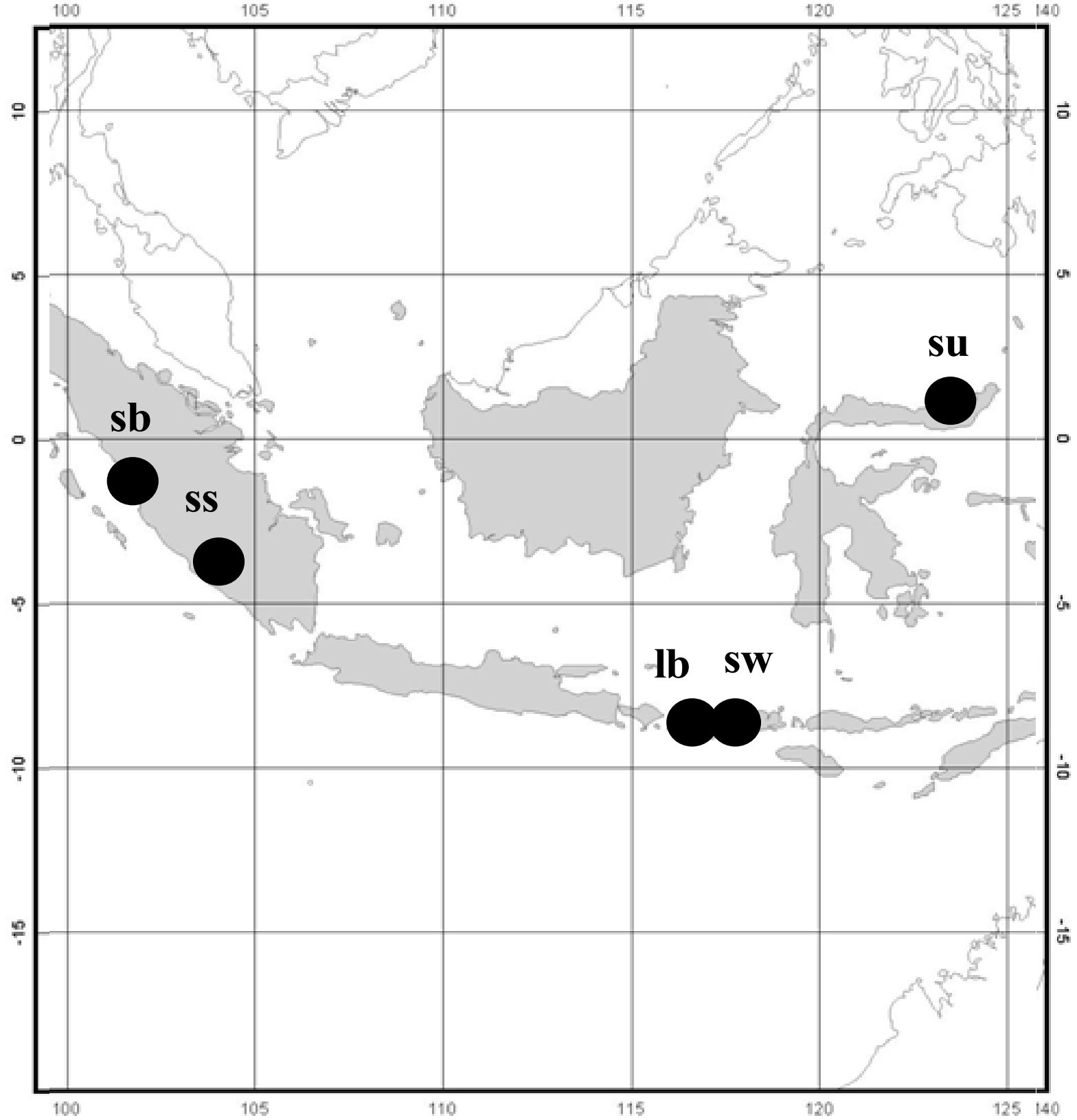

Keterangan: $\mathrm{lb}=$ Lombok Barat; $\mathrm{sw}=$ Sumbawa; $\mathrm{sb}=$ Sumatera Barat; ss=Sumatera Selatan; su=Sulawesi Utara

Gambar 1. Sebaran alam empat populasi jabon putih dan satu populasi jabon merah yang digunakan sebagai bahan kegiatan penelitian 
Tabel 1. Sekuen primer RAPD dan jumlah lokus polimorfik pada jabon

\begin{tabular}{|c|c|c|c|c|c|c|c|c|}
\hline $\begin{array}{c}\text { Nama } \\
\text { populasi }\end{array}$ & Jenis & $\begin{array}{c}\text { Kode } \\
\text { populasi }\end{array}$ & Wilayah & $\begin{array}{c}\text { Jum- } \\
\text { lah } \\
\text { contoh }\end{array}$ & $\begin{array}{l}\text { Keting- } \\
\text { gian tem- } \\
\text { pat } \\
(\mathrm{m} \mathrm{dpl})\end{array}$ & Letak as & ronomis & $\begin{array}{l}\text { Sifat tempat tum- } \\
\text { buh }\end{array}$ \\
\hline $\begin{array}{l}\text { Lombok } \\
\text { Barat }\end{array}$ & $\begin{array}{l}\text { Jabon } \\
\text { putih }\end{array}$ & $\mathrm{lb}$ & NTB & 12 & $20-400$ & $\begin{array}{l}08^{\circ} 48^{\prime} 19^{\prime \prime} \text { LS } \\
-08^{\circ} 51^{\prime} 39^{\prime \prime} \\
\text { LS }\end{array}$ & $\begin{array}{l}116^{\circ} 01^{\prime} 37^{\prime \prime} \\
\text { BT- } \\
116^{\circ} 03 \text { '08,4', } \\
\text { BT }\end{array}$ & $\begin{array}{l}\text { Tumbuh di tepi } \\
\text { laut, sepanjang } \\
\text { aliran sungai, } \\
\text { tempat terbuka } \\
\text { pada dataran } \\
\text { rendah dan } \\
\text { perbukitan }\end{array}$ \\
\hline Sumbawa & $\begin{array}{l}\text { Jabon } \\
\text { putih }\end{array}$ & sw & NTB & 9 & $75-400$ & $\begin{array}{l}8^{\circ} 6^{\circ} \mathrm{LS}- \\
9^{\circ} 5^{\circ} \mathrm{LS}\end{array}$ & $\begin{array}{l}117^{\circ} 42^{،} \mathrm{BT}- \\
118^{\circ} 30^{\circ} \mathrm{BT}\end{array}$ & $\begin{array}{l}\text { Tumbuh di } \\
\text { sepanjang aliran } \\
\text { sungai, tempat } \\
\text { terbuka pada } \\
\text { dataran rendah, } \\
\text { dan perbukitan }\end{array}$ \\
\hline $\begin{array}{l}\text { Sumatera } \\
\text { Barat }\end{array}$ & $\begin{array}{l}\text { Jabon } \\
\text { putih }\end{array}$ & $\mathrm{sb}$ & Sumatera & 12 & $200-700$ & $\begin{array}{l}00^{\circ} 18^{\prime} 45^{\prime \prime} \mathrm{LU} \\
-00^{\circ} 22^{\prime} 30^{\prime \prime} \\
\text { LU }\end{array}$ & $\begin{array}{l}100^{\circ} 00^{\prime} 00^{\prime \prime} \\
\text { BT - } \\
100^{\circ} 07^{\prime} 30^{\prime \prime} \\
\text { BT }\end{array}$ & $\begin{array}{l}\text { Sebagian besar } \\
\text { tumbuh di tepi } \\
\text { sungai }\end{array}$ \\
\hline $\begin{array}{l}\text { Sumatera } \\
\text { Selatan }\end{array}$ & $\begin{array}{l}\text { Jabon } \\
\text { putih }\end{array}$ & Ss & Sumatera & 16 & $40-100$ & $\begin{array}{l}3^{\circ} 02^{\prime} \mathrm{LS}- \\
3^{\circ} 48^{\prime} \mathrm{LS}\end{array}$ & $\begin{array}{l}104^{\circ} 20^{\prime} \text { BT- } \\
104^{\circ} 48^{\prime} \text { BT }\end{array}$ & $\begin{array}{l}\text { Tumbuh di daerah } \\
\text { rawa air tawar, } \\
\text { daratan yang } \\
\text { tergenang secara } \\
\text { periodik dan } \\
\text { daratan yang tidak } \\
\text { tergenang }\end{array}$ \\
\hline $\begin{array}{l}\text { Sulawesi } \\
\text { Utara }\end{array}$ & $\begin{array}{l}\text { Jabon } \\
\text { merah }\end{array}$ & $\mathrm{su}$ & Sulawesi & 36 & $15-580$ & $\begin{array}{l}00^{\circ} 49^{\prime} 20,72^{\prime \prime} \\
\text { LU - } \\
01^{\circ} 34^{\prime} 23,6^{\prime \prime} \\
\text { LU }\end{array}$ & $\begin{array}{l}123^{\circ} 53^{\prime} 53,15^{\prime}, \\
\text { BT - } \\
124^{\circ} 53^{\prime} 52^{\prime \prime} \\
\text { BT }\end{array}$ & $\begin{array}{l}\text { Sebagian besar } \\
\text { tumbuh di dekat } \\
\text { aliran air atau di } \\
\text { tepi sungai dan } \\
\text { tanah berbatu }\end{array}$ \\
\hline
\end{tabular}

\section{B. Ekstraksi DNA dan analisis RAPD}

Untuk mendapatkan total DNA, contoh daun seberat $50 \mathrm{mg}$, yang telah dikeringkan menggunakan silika gel, diekstraksi menggunakan metode CTAB (Shiraishi and Watanabe, 1995). Larutan PCR terdiri dari $10 \mu \mathrm{L}$ yang merupakan campuran dari $10 \mathrm{x}$ buffer stoffel, $3 \mathrm{mM} \mathrm{MgCl}{ }_{2}, 0,2 \mathrm{mM} \mathrm{dNTP}$, 0,05 Unit AmpliTaq stoffel polymerase, $10 \mu \mathrm{M}$ primer RAPD dan $10 \mathrm{ng} / \mu \mathrm{L}$ total DNA. Kondisi PCR terdiri dari denaturasi pada suhu $94^{\circ} \mathrm{C}$ selama 5 menit, dilanjutkan dengan 45 siklus yang terdiri dari denaturasi ( $94{ }^{\circ} \mathrm{C}$ selama 1,5 menit), penempelan primer $\left(37{ }^{\circ} \mathrm{C}\right.$ selama 30 detik) dan pemanjangan untai DNA $\left(70{ }^{\circ} \mathrm{C}\right.$ selama $\left.30{ }^{\circ} \mathrm{C}\right)$, kemudian pemantapan pada suhu $70{ }^{\circ} \mathrm{C}$ selama 5 menit. Proses PCR dilakukan menggunakan mesin thermal cycler GeneAmp PCR system 9700 (Applied Biosystem).

Penelitian ini menggunakan 8 primer RAPD yang telah berhasil discreening dari penelitian sebelumnya dengan total lokus polimorfik sebanyak 37 (Sukenda, data tidak dipublikasikan, Tabel 2.) 
Tabel 2. Sekuen primer RAPD dan jumlah lokus polimorfik pada jabon

\begin{tabular}{lllll}
\hline No. & Nama primer & Sekuen (5'-3') & $\begin{array}{c}\text { Jumlah lokus } \\
\text { polimorfik }\end{array}$ & $\begin{array}{c}\text { Ukuran lokus polimorfik } \\
(\mathrm{bp})\end{array}$ \\
\hline 1. & OPA1 & CAGGCCCTTC & 5 & $300,490,500,550,600$ \\
2. & OPA4 & AATCGGGCTG & 5 & $300,350,450,520,550$ \\
3. & OPA7 & GAAACGGGTG & 3 & $350,450,550$ \\
4. & OPA12 & TCGGCGATAG & 5 & $400,500,700,800,900$ \\
5. & OPA19 & CAAACGTCGG & 5 & $300,350,400,600,700$ \\
6. & OPQ14 & GGACGCTTCA & 3 & $450,550,650$ \\
7. & OPQ15 & GGGTAACGTG & 6 & $380,420,600,650,700$, \\
8. & OPQ16 & AGTGCAGCCA & 5 & 750 \\
\hline \multicolumn{5}{c}{37} \\
\hline
\end{tabular}

\section{Analisis Data}

Parameter keragaman genetik di dalam populasi yang digunakan adalah jumlah allele yang terdeteksi, jumlah alel privat (alel yang hanya dimiliki oleh satu populasi saja), jumlah alel yang jarang muncul (rare; frekuensi $<=50 \%$ ) dan nilai keragaman genetik $\left(H_{\mathrm{E}}\right)$. Analisis prinsip koordinat (Principle Coordinate Analysis; PCA) dilakukan untuk menguji kedekatan genetik dengan posisi geografis antar individu. Parameter keragaman genetik dan PCA dianalisis menggunakan program komputer GenAlex (Peakall and Smouse, 2012).

\section{HASIL DAN PEMBAHASAN}

\section{A. Hasil}

1. Keragaman genetik di dalam populasi

$$
\text { Berdasarkan } 37 \text { lokus RAPD }
$$

polimorfik, jumlah alel pada masing-masing populasi jabon putih berkisar antara 17 (Sumatera Selatan) - 31 (Sumbawa) dan 30 pada jabon merah. Jumlah allele privat hanya dimiliki oleh populasi Sumatera Selatan (sebanyak 2 alel). Alel yang jarang muncul (rare allele) dimiliki oleh hampir semua populasi baik jabon putih maupun jabon merah, kecuali populasi Sumatera Barat. Jumlah rare allele pada jabon putih berkisar antara 3 (Sumatera Selatan) - 6 (Sumbawa), dan sejumlah 2 alel pada jabon merah. 
Tabel 3. Nilai keragaman genetik di dalam empat populasi jabon putih dan satu populasi jabon merah berdasarkan 37 lokus polimorfik RAPD

\begin{tabular}{|c|c|c|c|c|c|c|}
\hline Nama populasi & $\begin{array}{c}\text { Kode } \\
\text { populasi }\end{array}$ & $\mathrm{N}$ & $\begin{array}{l}\text { Jumlah } \\
\text { alel }\end{array}$ & $\begin{array}{c}\text { Jumlah alel } \\
\text { privat }\end{array}$ & $\begin{array}{l}\text { Jumlah } \\
\text { rare allele }\end{array}$ & $H_{\mathrm{E}}(\mathrm{SE})$ \\
\hline Lombok Barat & $\mathrm{Lb}$ & 12 & 23 & 0 & 4 & $0,196(0,036)$ \\
\hline Sumbawa & Sw & 9 & 31 & 0 & 6 & $0,315(0,033)$ \\
\hline Sumatera Barat & $\mathrm{Sb}$ & 12 & 18 & 0 & 0 & $0,136(0,032)$ \\
\hline Sumatera Selatan & Ss & 16 & 17 & 2 & 3 & $0,171(0,034)$ \\
\hline $\begin{array}{l}\text { Jumlah/Rerata } \\
\text { nilai keragaman } \\
\text { jabon putih }\end{array}$ & & 49 & 22,3 & 2 & 4.3 & 0,204 \\
\hline Sulawesi Utara & $\mathrm{Su}$ & 36 & 30 & 0 & 2 & $0,200(0,025)$ \\
\hline
\end{tabular}

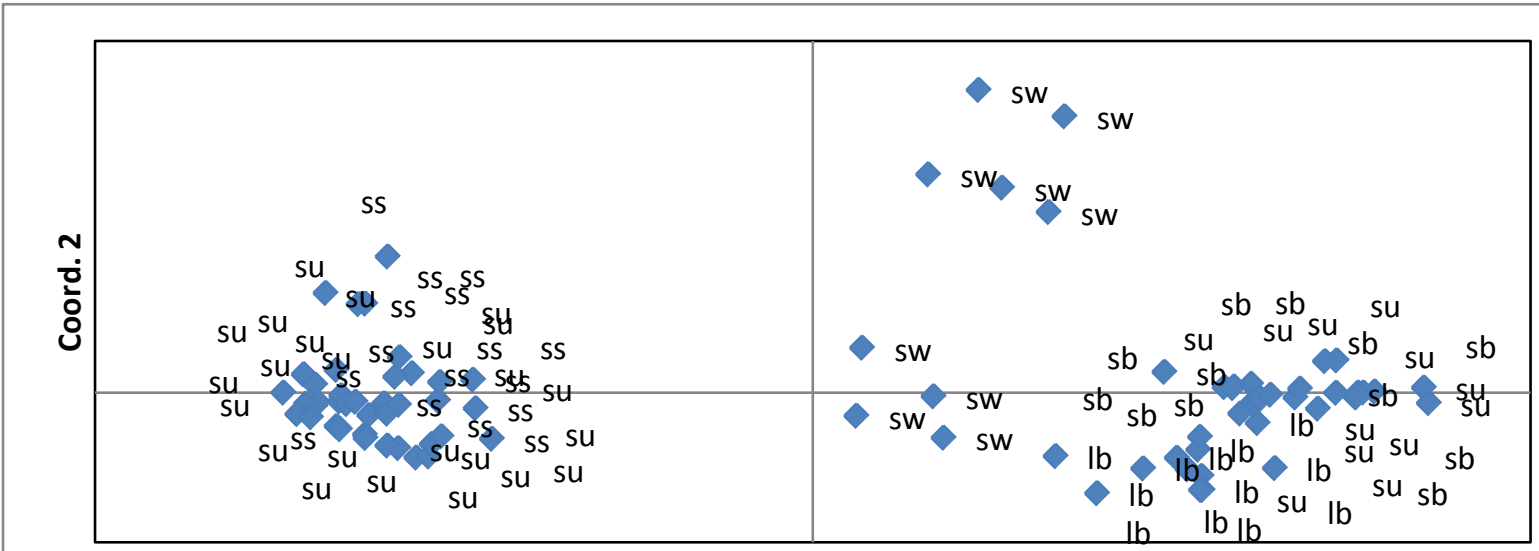

Coord. 1

Keterangan: $\mathrm{lb}=$ =Lombok Barat; $\mathrm{sw}=$ Sumbawa; sb=Sumatera Barat; ss=Sumatera Selatan; su=Sulawesi Utara Gambar 2. Analisis prinsip kordinat individu dalam populasi jabon putih dan jabon merah

Banyaknya jumlah alel yang terdeteksi, alel khusus dan rare alel menentukan nilai heterozigositas harapan $\left(H_{\mathrm{E}}\right)$. Populasi jabon putih dari wilayah NTB (Lombok Barat dan Sumbawa) mempunyai nilai keragaman yang lebih tinggi dibandingkan nilainya dari wilayah Sumatera (Sumatera Barat dan Sumatera Selatan). Nilai $H_{\mathrm{E}}$ pada populasi jabon putih berkisar antara 0,136 (Sumatera
Barat) - 0,315 (Sumbawa) dengan nilai ratarata sebesar 0,204, sedangkan nilai $H_{\mathrm{E}}$ pada jabon merah adalah 0,200.

2. Analisis prinsip koordinat

Analisis prinsip koordinat menunjukkan bahwa populasi jabon putih dari wilayah NTB (Lombok Barat dan Sumbawa) saling berdekatan baik secara geografis maupun genetik. Populasi dari 
wilayah Sumatera (Sumatera Barat dan Sumatera Selatan), walaupun berdekatan secara geografis namun berjauhan secara genetik. Populasi Sumatera Barat berada dalam ordinat yang sama dengan populasi Lombok Barat maupun Sumbawa. Sebagian individu jabon merah (su) berada dalam ordinat yang sama dengan populasi Sumatera Selatan, sebagian individu berada dalam ordinat yang sama dengan populasi Lombok Barat dan Sumbawa.

\section{B. Pembahasan}

1. Keragaman genetik di dalam populasi

Berdasarkan 37 penanda RAPD polimorfik, rata-rata keragaman genetik jabon putih termasuk dalam nilai yang sedang (rata-rata $\left.H_{\mathrm{E}}=0,204\right)$ apabila dibandingkan dengan jenis lain (rata-rata $H_{\mathrm{E}}$ nyamplung $=0,186$; Nurtjahjaningsih dkk, submitted 2014). Demikian pula dengan nilai keragaman genetik jenis jabon merah $\left(H_{\mathrm{E}}=0,200\right)$. Seperti disebutkan di atas bahwa sebaran tegakan jabon putih cukup luas, hampir di seluruh pulau di Indonesia. Tegakan dengan sebaran geografis yang luas cenderung mempunyai keragaman genetik tinggi di dalam populasi, dan mempunyai struktur populasi yang lemah (Giang et al.,
2006; Tsuda and Ide, 2005).

Habitat terpisah-pisah dan konversi lahan menyebabkan ukuran populasi jabon putih di wilayah Sumatera lebih kecil dibandingkan di NTB. Salah satu konsekuensi dari kecilnya ukuran populasi adalah rendahnya jumlah alel dan nilai keragaman genetik $\left(H_{\mathrm{E}}\right)$ (Tabel 2). Populasi-populasi yang menyambung mempunyai ukuran populasi yang lebih tinggi dibandingkan populasi terpisah-pisah sehingga mendorong terjadinya aliran gen (gene flow) yang tidak terbatas. Seperti pada populasi Acacia mangium, sifat sebaran alam yang menyambung di Queensland diduga menyebabkan tingginya nilai keragaman genetik dibandingkan sebaran alam yang terpisah-pisah di PNG (Butcher et al., 1998). Nilai keragaman genetik sering dikaitkan dengan ukuran populasi suatu jenis. Ukuran populasi yang lebih rendah di wilayah Sumatera dapat menjadi salah satu faktor penyebab rendahnya nilai keragaman genetik populasi di wilayah tersebut. Ukuran populasi kecil menyebabkan tingginya penyimpangan keragaman genetik, damparan genetik sebagai pengaruh populasi leher botol (bottleneck) akibat menurunnya jumlah individu dalam suatu populasi, serta 
perkawinan kerabat (inbreeding) (Angeloni et al., 2014; Cusker et al., 2014; Edwards et $a l .$, 2014). Penyimpangan genetik dikaitkan dengan proses perubahan frekuensi alel pada kemampuan beradaptasi dan bereproduksi; sedangkan pengaruh populasi leher botol dihubungkan dengan menurunnya ukuran populasi yang menyebabkan peningkatan peluang untuk tidak diwariskannya alel tertentu, serta berpotensi meningkatkan frekuensi kawin kerabat.

Jabon putih di Sumatera Selatan tumbuh di daerah pasang-surut sementara dan wilayahnya cukup terisolasi oleh perbukitan (Tabel 1). Walaupun, nilai keragaman genetik pada populasi ini lebih rendah dibandingkan di wilayah NTB, namun nilainya masih cukup tinggi dibandingkan populasi Sumatera Barat. Selain itu, populasi Sematera Selatan merupakan satu-satunya populasi yang mempunyai alel privat. Oleh karena itu pengaruh leher botol dan kawin kerabat mungkin bukan suatu alasan rendahnya keragaman genetik pada populasi ini dibandingkan dengan populasi di wilayah NTB. Pada ukuran populasi kecil beberapa jenis menunjukkan evolusi adaptasi yang ditunjukkan dengan perubahan frekuensi allele dalam proses penyimpangan genetik
(Radespiel and Bruford, 2014). Edwards dkk. (2014) melaporkan bahwa tingginya keragaman genetik pada pada populasi Erigeron lemmoni menunjukkan bahwa kecilnya ukuran populasi pada tingkatan/nilai tertentu tidak disebabkan karena pengaruh leher botol maupun kawin kerabat, namun disebabkan oleh penyimpangan genetik. Sedangkan rendahnya keragaman genetik di populasi Sumatera Barat menunjukkan pengaruh leher botol atau terjadinya proses kawin kerabat.

2. Keragaman genetik antar populasi

Analisis prinsip koordinat menunjukkan populasi Sumatera Barat berada pada satu ordinat dengan populasi Lombok Barat dan Sumbawa. Banyak faktor yang mengakibatkan pencampuran gen antar populasi, diantaranya pencampuran secara alami melalui perkawinan/hibridisasi, persamaan nenek moyang (refugia) atau peran manusia baik domestikasi maupun budidaya (Giang et al., 2006; Hu et al., 2010; Lusini et al., 2014; Peters et al., 2014). Pencampuran gen secara alami disebabkan proses aliran gen antar populasi melalui sebaran serbuk sari maupun melalui biji (Dow and Ashley, 1998). Proses aliran sering dikaitkan dengan jarak geografis 
populasi. Semakin dekat jarak geografis maka proses aliran gen tidak terhalang sehingga jarak genetik semakin dekat (Tsuda and Ide, 2005). Pencampuran gen pada hutan di daerah temperate terjadi karena pada masa glasial (es), semua dataran menyatu, sehingga banyak persamaan refugia $(\mathrm{Hu}$ et al., 2010). Pencampuran gen antar populasi yang paling sering terjadi diakibatkan oleh peran manusia. Banyak penelitian yang melaporkan bahwa manusia banyak berperan dalam membentuk struktur genetik suatu populasi, domestikasi maupun mencampur asal-usul (Cusker et al., 2014; Lusini et al., 2014). Pada jenis kacang-kacangan yang sudah didomestikasi, pencampuran gen berasal dari beberapa gene pool sehingga zona pencampuran tersebut memiliki keragaman genetik yang tinggi (Lusini et al., 2014). Berdasarkan telaah di atas, proses gene flow secara alami dari populasi Sumatera Barat ke populasi di wilayah NTB tidak mungkin terjadi karena jarak geografis yang terlalu jauh $( \pm 2,000 \mathrm{~km})$. Persamaan refugia antar populasi Sumatera Barat dan populasi di wilayah NTB juga sulit dipahami karena tidak pernah ada laporan tentang penyatuan secara geografis wilayah Sumatera dan NTB. Kesamaan struktur genetik antara populasi Sumatera Barat dan NTB hanya dapat didekati dengan pencampuran gen yang diperankan oleh manusia. Jabon putih sudah dibudidayakan dan disebarkan sejak waktu yang lama dan mudah diperbanyak secara vegetatif, sehingga perpindahan sumber genetik dalam hal ini lebih diperankan oleh campur tangan manusia.

Sebaliknya, analisis prinsip koordinat menunjukkan populasi Sumatera Barat terpisah dari populasi Sumatera Selatan, meskipun mempunyai jarak geografis yang relatif lebih dekat dari 2 populasi jabon putih lainnya. Sebaran populasi yang luas, bisa menghilangkan sifat gen yang unik dari suatu populasi (Assis et al., 2014). Hal ini yang mungkin terjadi pada populasi Sumatera Barat. Adanya alel privat pada populasi Sumatera Selatan menunjukkan populasi tersebut tidak terkontaminasi oleh 3 populasi jabon putih lainnya. Kemurnian genetik bisa terjaga karena penghalang geografis maupun antroplogis seperti pegunungan, sungai, laut, bendungan, jalan layang dan berkurangnya peran manusia (Baumsteiger and Aguilar, 2014; Boutilier et al., 2014; Ng et al., 2014; Prunier et al., 2014). 


\section{KESIMPULAN DAN REKOMENDASI}

Berdasarkan 37 lokus RAPD, jabon putih mempunyai nilai keragaman genetik dalam kategori sedang. Perbedaan genetik antar empat populasi yang digunakan menunjukkan nilai yang tidak nyata, sehingga dalam menyusun strategi konservasi tidak memerlukan populasi dalam jumlah banyak. Populasi Sumbawa dan Sumatera Selatan cukup berpotensi untuk ditanam di plot konservasi karena mempunyai nilai keragaman genetik tinggi dan allele privat. Selain itu, adanya alel privat yang dimiliki oleh populasi Sumatera Selatan menyebabkan populasi ini harus ditanam secara terpisah untuk menjaga kemurnian gen dari populasi ini. Adanya proses aliran gen atau pencampuran gene pool antar populasi menyebabkan kedekatan secara geografis tidak selalu menunjukkan kedekatan secara genetik.

\section{UCAPAN TERIMA-KASIH}

Penulis menyampaikan terima kasih kepada Bapak Y. Triyanta dan Ibu Wahyunisari yang telah membantu pekerjaan di lapangan maupun di laboratorium.

\section{DAFTAR PUSTAKA}

Angeloni, F., Vergeer, P., Wagemaker, C. A. M. and Ouborg, N. J. (2014). Within and between population variation in inbreeding depression in the locally threatened perennial Scabiosa columbaria. Conserv Genet, 15: 331342.

Assis, J., Serrao, E. A., Claro, B., Perrin, C. and Perason, G. A. (2014). Climate-driven range shifts explain the distribution of extant gene pools and predict future loss of unique lineages in a marine brown alga. Molecular Ecology, 23: 2797-2810.

Baumsteiger, J., and Aguilar, A. (2014). Impact of dams on distribution, population structure, and hybridization of two species of California freshwater sculpin (Cottus). Conserv Genet, 15: 729-742.

Boutilier, S. T., Taylor, S. A., Morris-Pocock, J. A., Lavoie, R. A. and Friesen, V. L. (2014). Evidence for genetic differentiation among Caspian tern (Hydroprogne caspia) populations in North America. Conserv Genet, 15: 275 281.

Butcher, P. A., Moran, G. F. and Perkins, H. D. (1998). RFLP diversity in the nuclear genome of Acacia mangium. Heredity, 81: 205-213.

Cusker, M. R. M., Mandrak, N. E., Egeh, B. and Lovejoy, N. R. (2014). Population structure and conservation genetic assessment of the endangered Pugnose Shiner, Notropis anogenus. Can. J. For. Res, 15: 343-353.

Dow, B. D. and Ashley, M. V. (1998). High levels of gene flow in bur oak revealed by paternity analysis using microsatellites. Journal of Heredity, 89: 62-70.

Edwards, C. E., Lindsay, D. L., Bailey, P. and Lance, R. F. (2014). Pattern of genetic diversity in the rare Erigeron lemmoni and comparison with its more widespread congerer, Erigeron arisolius (Asteraceae). Conserv Genet, 15: 419428.

Giang, L. H., Geada, G. L., Hong, P. N., Tuan, M. S., Lien, N. T. H., Ikeda, S. and Harada, K. (2006). Genetic variation of two mangrove species in Kandelia (Rhizophoraceae) in Vietnam 
and surrounding area revealed by microsatellite markers. Int. J. Plant Sci., 167(2): 291-298.

Hamrick, J. L., Godt, M. J. W. and ShermanBroyless, S. L. (1992). Factor influencing levels of genetic diversity in woody plant species. New Forest, 6: 95-124.

Hu, L.-J., Uchiyama, K., Saito, Y. and Ide, Y. (2010). Contrasting patterns of nuclear microsatellite genetic structure of Fraxinus mandshurica var. japonica between northern and southern populations in Japan. Journal of Biogeography (J. Biogeogr), 37: 11311143.

Krisnawati, H., Kallio, M. and Kanninen, M. (2011). Anthocephalus cadamba Miq. Ekologi, Silvikultur dan Produktivitas: CIFOR pp. 22.

Lusini, I., Velichkov, I., Pollegioni, P., Chiocchini, F., Hinkov, G., Zlatanov, T., Cherubini, M. and Mattioni, C. (2014). Estimating the genetic diversity and spatial structure of Bulgarian Castanea sativa populations by SSRs: implications for conservation. Conserv Genet, 15: 283-293.

Manoel, R. O., Alves, P. F., Dourado, C. L., Gaino, A. P. S. C., Freitas, M. L. M., Moraes, M. L. T. and Sebbenn, A. M. (2012). Contemporary pollen flow, mating patterns and effective population size inferred from paternity analysis in a small fragmented population of the Neotropical tree Copaifera langsdorffii Desf. (Leguminosae-Caesalpinioideae). Conserv Genet, 13: 613-623.

Moriguchi, Y., Taira, H., Tani, N. and Tsumura, Y. (2004). Variation of paternal contribution in a seed orchard of Cryptomeria japonica determind using microsatellite markers. Can. J. For. Res, 34: 1683-1690.
Ng, J., Clemann, N., Chapple, S. N. J. and Melville, J. (2014). Phylogeographic evidence links the threatened 'Grampians' Mountain Dragon (Rankinia diemensi Grampians) with Tasmanian populations: conservation implications in south-eastern Asutarlia. Conserv Genet, 15: 363-373.

Peakall, R. and Smouse, P. E. (2012). GenAlEx 6.5: genetic analysis in excel. Population genetic software for teaching and research -an update. Bioinformatics Applications Note, 28(19): 2537-2539.

Peters, J. L., Sonsthagen, S. A., Lavretsky, P., Rezsutek, M., Johnson, W. P. and McCracken, K. G. (2014). Interspecific hybridization contributes to high genetic diversity and apparent effective population size in an endemic population of mottled ducks (Anas fulvigula maculosa). Conserv Genet, 15: 509-520.

Prunier, J. G., Kaufmann, B., Lena, J.-P., Fenet, S., Pompanon, F. and Joly, P. (2014). A 40-year-old divided highway does not prevent gene flow in the alpine newt Ichthyosaura alpestris. Conserv Genet, 15(453-468).

Radespiel, U. and Bruford, M. W. (2014). Fragmentation genetics of ranforest animal: insght from recent studies. Conserv Genet, 15: 245-260.

Shiraishi, S. and Watanabe, A. (1995). Identification of chloroplast genome between Pinus densiflora Sieb et Zucc and $P$. thumbergii Parl based on the polymorphism in $r b c \mathrm{~L}$ gene. Journal of Japanese Forestry Society, 77: 429-436.

Tsuda, Y. and Ide, Y. (2005). Wide-range analysis of genetic structure of Betula maximowicziana, a long-lived pioneer tree species and noble hardwood in the cool temperate zone of Japan. Molecular Ecology, 14: 3929-3941. 